\title{
Attitudes towards Organizational Change among Public Middle Managers
}

\begin{abstract}
Positive attitudes towards change (PATC) are an important current issue in public organizations facing profound financial, and managerial reforms. This study aims to identify social and organizational antecedents of PATC. The investigated population is composed of middle managers working in Swiss public hospitals $(\mathrm{N}=720)$, which are currently being confronted by major reforms. Partial mediation effects of organizational commitment in the relationships between independent variables and PATC are also controlled. The findings show that perceived social support (work relationships with colleagues and supervisors) as well as perceived organizational support (employee voice and participation; information and communication; work-life balance) are positively and significantly related to PATC. Stress perception is shown to have a negative impact on PATC. This article provides valuable contributions with respect to antecedents of attitudes towards change in a population of public middle managers.
\end{abstract}

Keywords - attitudes towards change; public hospitals; public management reforms; middle managers; social exchange theory.

Corresponding author:

David Giauque

University of Lausanne

Institute of political and international studies

Géopolis

1015 Lausanne

Switzerland

Email address: David.Giauque@unil.ch

Phone number: ++41216923637

Fax number: ++41216923145 


\section{Introduction}

Public organizations have been confronted with multiple reforms since the 1990s. More specifically, public hospitals are now contending with several organizational, and managerial reforms throughout the world (Fisher et al., 2004; Kirkpatrick et al., 2009; Kuhlmann et al., 2009; Spirig et al., 2014). The wave of such reforms is clearly connected to the budget and fiscal crises about which most OECD countries are dealing. Nevertheless, it is evident that the way in which public employees deal with organizational reforms is a topic that has been thus far neglected. According to a recent article presenting a review of the literature on change management in public organizations, there is a lack of research on "the factors that influence the change process and determine its success or failure“"(Kuipers et al., 2014: 15). Of course, one can identify numerous articles and books regarding organizational change (Clary et al., 2000; Heckscher \& Donnellon, 1994; Jones, 2007) and organizational readiness for change and learning (Argyris \& Schön, 1996; Caldwell, 2011). However, although the extant literature might be concerned with antecedents of organizational change, they only marginally address the central question related to the antecedents of positive attitudes towards change (PATC) among members of organizations confronted with profound financial, and managerial transformations. Furthermore, the majority of the publications dedicated to change management issues have a US/Anglo-Saxon origin which are potentially biased with respect to results (Kuipers et al., 2014: 6).

Why is it important to study PATC? First of all, because social science literature suggests that PATC is related to positive work outcomes such as organizational citizenship behavior (OCB) (Chih et al., 2012). Furthermore, recent literature also demonstrates that organizational change may create stress because of uncertainty. This uncertainty may, in turn, affect the job commitment and job satisfaction of employees and therefore affect their performance. "When public sector employees have a negative perception of organizational changes, massive work stress will arise. If such stress cannot be relieved, employees work attitudes and performance will inevitably be affected“ (Yu, 2009: 28). In other words, this article builds upon the assumption that PATC might contribute positively to work outcomes and organizational performance and that it creates a positive atmosphere regarding organizational innovation. 
Based on a grounding in social exchange theory, this paper identifies several organizational conditions which could create a positive organizational atmosphere that employees might interpret as organizational support for their work. With such a positive perception of their organizational environment, employees are likely to develop a more positive perception of organizational reforms. With that said, one can also hypothesize that these organizational conditions could contribute to the creation of a positive feeling of organizational commitment which could in turn mediate the relationship between organizational conditions and PATC. The main research questions of this paper are therefore: Which organizational antecedents are related to PATC? And are the relationships between organizational conditions and PATC mediated by organizational commitment (OC)?

This study has two main objectives. First, we aim to uncover new insights regarding the organizational antecedents of individual attitudes towards current reforms in the public sector. Basing our analysis on the literature on attitudes towards organizational change and high commitment human resources practices (HCHRP), we try to explain how social and organizational support may be related to PATC. In turn, we will also identify whether the association between social and organizational antecedents of PATC are mediated by OC. Indeed, one can suppose that several working conditions might contribute to favoring OC among employees. Employees reporting higher levels of OC will probably also report higher PATC. The mediating effect of OC in the relationship between working conditions and PATC will therefore be studied in this article. Furthermore, the originality of this paper also lies in the specific population we investigate, as our empirical inquiry concerns middle managers working in public hospitals in Switzerland. According to the literature, middle managers are key actors in reform processes (Harding et al., 2014). They play a pivotal role between executive officers and employees, and have important functions. They translate formal and administrative rules into practical working rules, coordinate the work of their subordinates, are in charge of work control (quality control and expense control), manage conflicts in their team, and pass important information from the bottom up. In other words, middle managers are pivotal actors in the processes of change and its management. Furthermore, the population investigated works in public hospitals situated in the French-speaking Swiss cantons, which are currently under immense pressure with budget cuts and a new legal framework that changes the financial conditions with which they have to work. In this context, public hospitals also began changes regarding management and organizational structures. It 
is therefore of particular interest to study this specific population given the changing conditions of public hospitals.

The first part of this article will be dedicated to a literature review to clarify our theoretical framework. Secondly, we will present the main variables included in our analysis. Thirdly, we present the context of our study to outline the reforms regarding public hospitals in Switzerland. The fourth section is dedicated to our methodology and the presentation of our sample. The fifth section will address the main results of our research with a discussion and conclusion which will include the limitations of the present study.

\section{Theoretical framework and hypotheses}

Before addressing the theoretical linkage between the different variables of our study, we will set the general framework of this study, which focuses on exchanges between employees and their organization.

\subsection{A social exchange perspective}

According to many academics, coordination and cooperation in organizations are primarily a matter of reciprocal exchanges between employees and employers (Blau, 1964; Homans, 1961; March \& Simon, 1964). Employers offer material and immaterial work conditions to employees and in turn, employees reciprocate organizational efforts by working hard. In other words, the employment relationship can be viewed as consisting of social and/or economic exchanges (Eisenberger et al., 1990; Gould-Williams \& Davies, 2005). Anthropologists have demonstrated that relationships between individuals are also a matter of reciprocal gifts (Caillé, 1997; Mauss, 1985 [1950]): "Social exchange theory highlights the importance of understanding employees' motivation and its relation to the achievement of organizational goals. Such approaches to organizational behavior incorporate employees' motive to carry out specific activities within the mutual obligations between employees and employers" (Aselage \& Eisenberger, 2003: 492). Of course, different theoretical conceptions of social exchange do exist, as with organizational support theory (OST) (Eisenberger et al., 1990; Rhoades et al., 2001; Shore \& Coyle-Shapiro, 2003) and psychological contract theory (PCT) (Rousseau, 1995; Wooldridge, 2001). According to the precepts of organizational support theory (OST), employees perceive favorable or unfavorable treatment from their organization and develop feelings of obligation or dissatisfaction towards their organization accordingly. They perceive their 
organization's treatment of them as an indication of the "extent to which the organization values their contributions and cares about their well-being" (Aselage \& Eisenberger, 2003: 493). In other words, favorable work experiences may create a feeling of organizational support. Thus, perceived organizational support is built according to favorable work experiences that employees may encounter in their organization $^{1}$. We are also aware that perceived organizational support in public organizations has several origins. For instance, many interested stakeholder groups may have important impacts on perceived organizational support (e.g. politicians, clients, interest groups, the media, and so on) (Carpenter, 2001; Rourke, 1984). Nevertheless, in the present study, we will mainly focus our attention on internal and organizational factors affecting perceived organizational support.

PCT, for its part, departs from the idea that employees and organizations have mutual expectations concerning resources and work conditions. According to Rousseau (Rousseau, 1995; Rousseau, 1997), we may define a psychological contract as employees' perceptions of the mutual obligations existing between themselves and their organization. Although the two theories have only small differences, both "OST and PCT incorporate the exchange of socioemotional resources, promoted by the reciprocity norm, as an important aspect of the development of exchange relationships between employees and their work organization" (Aselage \& Eisenberger, 2003: 497).

For our own purposes, it is important to note that favorable organizational treatment may create favorable conditions that build a positive relationship between employees and their organization. In other words, perceived organizational support is related to positive job outcomes, such as organizational commitment, job satisfaction, and intention to remain (Rhoades et al., 2001).

According to such previous theoretical considerations, we depart from the now well established theoretical point of view that favorable work conditions will necessarily create a positive feeling of perceived organizational support which, in turn, may induce PATC and organizational reforms among employees. In other words, employees' satisfaction toward formal work conditions may be positively related to positive attitudes towards organizational reforms precisely because they perceive favorable organizational support.

1 We have to stress here that this study does not measure perceived organizational support according to any preexisting well defined measurement instrument. Rather, arguments related to perceived organizational support are used theoretically in order to make an intellectual link between our dependent variable (PATC) and our independent variables (work relationships; stress perception; HRM practices). 
That said, even if perceived organizational support is related to favorable work conditions, employees' attitudes towards work are also related to the kinds of goals they have to reach (Locke \& Latham, 2002, 2006). In other words, the properties of the goals which are embedded in organizational reforms and changes do matter as well. Therefore, goal-setting theory is now a well-known theory stipulating that " (...) specific, high (hard) goals lead to a higher level of task performance than do easy goals or vague, abstract goals such as the exhortation to do one's best. So long as a person is committed to the goal, has the requisite ability to attain it, and does not have conflicting goals, there is a positive, linear relationship between goal difficulty and task performance" (Locke \& Latham, 2006: 265). Furthermore, the social science literature has shown that goal ambiguity may impact on individual and organizational performance in public organizations (Chan Su Jung \& Rainey, 2011; Wright, 2004). The characteristics of goals contained in the changes and reforms may then also have an impact on work attitudes and PATC. Nevertheless, this study will not investigate this specific dimension despite our awareness of the importance of the issue. This specific point might therefore be considered as a limitation to the present study.

\subsection{Attitudes towards organizational change}

In the context of our study, it may be useful to define what we mean by "attitudes towards change." According to Vakola and Nikolaou (2005: 162), "attitudes towards change in general consist of a person's cognitions about change, affective reactions to change, and behavioral tendency toward change. (...) Therefore, change can be received with excitement and happiness or anger and fear while employees' response to it may range from positive intentions to support the change to negative intentions to oppose it." With respect to social exchange theories, favorable work experiences made by employees in their organization may create perceived organizational support. This latter point may in turn favor the development of PATC.

According to the literature, positive attitudes to change and organizational reforms are clearly related to positive work outcomes. For instance, positive attitudes are helpful for attaining organizational goals and succeeding in reforms' processes (Eby et al., 2000; Gilmore \& Barnett, 1992; Kotter, 1996). Nevertheless, most organizational reforms are being met with resistance because actors are not willing to support them, 
they have to deal with too many reforms in a short period of time, or they are dealing with increased pressure and stress due to the never-ending reforms processes of their work environment (Giauque et al., 2013b; Rush et al., 1995). Furthermore, actors are more willing to collaborate and cooperate in a reform period when they feel that they are well informed and supported by their organization (Dupuy, 2004, 2011). Since perceived organizational support is clearly related to positive work outcomes such as job satisfaction and organizational commitment (Aselage \& Eisenberger, 2003; Eisenberger et al., 1990; Rhoades et al., 2001), as we have noted earlier in this study, it is therefore of great interest to identify organizational antecedents that affect attitudes towards change.

According to empirical evidence, it is possible to classify antecedents affecting attitudes towards change into three different categories. The first concerns the perceived social support or work relationships with colleagues and supervisors, as "more specifically, lack of a socially supportive environment was found to be the strongest predictor of negative attitudes towards change (...)" (Vakola \& Nikolaou, 2005: 169). In other words, work relationships with colleagues and supervisors may greatly affect attitudes to organizational change. Positive attitudes towards organizational reforms are clearly a matter of work relationships and person-group fit (Giauque et al., 2014). According to these above explanations we may formulate two hypotheses:

H1: Satisfaction in work relationships with colleagues is related to positive attitudes towards change (PATC).

H2: Satisfaction in work relationships with supervisors is related to PATC.

The second category of antecedents we can identify is related to work overload or the perception of stress at work. According to numerous studies related to this specific dimension, stress is negatively related to job outcomes such as job satisfaction or organizational commitment, or even attitudes towards change (Karasek \& Theorell, 1990; Noblet \& Rodwell, 2008; Richardsen et al., 1992; Vakola \& Nikolaou, 2005). Furthermore, with regards to the literature concerning middle managers, we may find that work-life balance is a central concern for these specific actors (Ford \& Collinson, 2011; Ford \& Harding, 2003; Whittle, 2008). If middle managers perceive that their work provides them with good opportunities for reconciling 
their private and professional lives, they will be likely to report more PATC. Therefore, we propose two hypotheses:

H3: Perceived stress at work will negatively impact attitudes towards change.

H4: Work-life balance will be positively related to PATC.

Finally, a third category of antecedents is related to work conditions or the administration of appropriate human resource practices. In order to identify such human resource practices, it is useful to look at the specialized literature dealing with HRM.

\subsection{High commitment HRM practices}

HRM practices may be classified by whether the objective is the control of employees or control of their commitment to the organization (Walton, 1985; Wood \& Menezes, 1998). The first category of HRM practices (control practices) is designed to increase organizational efficiency while reducing employment costs. These practices are based on strict rules and working procedures, as well as results-based financial rewards. Consequently, rules, procedures, penalties and rewards, as well as control, are the tools for implementing this HRM strategy.

On the other hand, high-performance HRM practices, also called "high commitment" HRM practices (Whitener, 2001) or "high-performance" work practices (Gould-Williams \& Davies, 2005; Kalleberg et al., 2006), can be described as a set of HRM practices that are intended to have an impact on employees' commitment towards their organization (Taylor et al., 2008). These HRM practices are devised to enhance the performance of employees while promoting mutual influence, respect, and responsibility (Huselid, 1995; Lindorff, 2009). They seek to develop organizational productivity and efficiency through the implementation of working conditions that enhance employees' ability to identify with organizational objectives and values. The practices generally associated with this second strategy include selective staffing, developmental appraisal, competitive and equitable compensation, and training and development activities (MacDuffie, 1995; Snell \& Dean, 1992; Youndt et al., 1996). Moreover, several surveys suggest that organizations that have adopted this type of HRM system often obtain better production and financial results (Delaney \& Huselid, 1996) while also enabling the development of creativity and innovation within 
their structures (Andriopoulos, 2001; Jimenez-Jimenez \& Sanz-Valle, 2005). As underlined particularly by MacDuffie (MacDuffie, 1995), the purpose of high-performance HRM practices is to motivate employees to adopt discretionary behaviors that are in line with the goals of the organization.

Although there is no clear list delineating high-performance HRM practices, we can nevertheless highlight that "theoretically they should increase involvement, and it has been suggested this can best occur through increasing workplace power, information on the organization, rewards and training and knowledge of the job" (Lindorff, 2009: 432). Therefore, empirical research has demonstrated that the commitment category of HRM practices is more likely to contribute to employee involvement and performance than those aspects oriented towards the control of individual behaviors (Whitener, 2001). Daley and Vasu, in their study of HRM practices in the public sector, identify seven general practices belonging to this category of strategic HRM practices: (1) internal career ladders; (2) formal training systems; (3) results-oriented performance appraisal; (4) employment security; (5) employee voice and participation; (6) broadly defined jobs; (7) performance-based compensation (Daley \& Vasu, 2005; Gould-Williams, 2003, 2007). For the purposes of our study and according to the organizational features and HRM practices of public hospitals in Switzerland, we decided to investigate six HR practices that are related to the commitment category of HRM practices (opportunities for professional development; training opportunities; employee voice and participation; information and communication; compensation; job security). According to the above theoretical considerations, we have decided not to include control practices but to focus instead on HR practices which have been proven to be associated with positive work attitudes in the recent social science literature (Gould-Williams, 2007; Gould-Williams et al., 2013; Messersmith et al., 2011). The choice to neglect control HR practices is therefore based on our chosen theoretical background and recent empirical research.

Empirically, the positive relationship between HCHRP and positive work outcomes, such as job satisfaction and affective commitment, has been examined and supported in a number of studies (Boselie, 2010; Gould-Williams et al., 2013; Messersmith et al., 2011). However, several studies used an overall measure of HCHRP (see for instance: Gould-Williams et al., 2013). Although this strategy is certainly interesting, it is not very useful for precisely identifying which HR practices influenced the most attitudes towards change. Therefore, we decided to test the relationships between HR practices and attitudes towards 
change individually. In this vein, we hypothesize direct positive relationships between HR practices and PATC. Therefore, we propose a new hypothesis divided into six sub-hypotheses:

H5a: Satisfaction related to professional development opportunities are related to PATC.

H5b: Satisfaction in relation to training opportunities are related to PATC.

H5c: Satisfaction with regard to employee voice and participation are related to PATC.

H5d: Satisfaction regarding compensation is related to PATC.

H5e: Satisfaction with respect to job security is associated with PATC.

H5f: Satisfaction with regard to information policy is related to PATC.

According to the HCHRP's literature and our theoretical framework (social exchange theory), favorable organizational conditions may create feelings of obligation among employees. In other words, if employees perceive that they might benefit from positive working conditions, they may increase their commitment towards their organization. As a result, perceived organizational support is related to positive job outcomes, such as organizational commitment (Rhoades et al., 2001). Moreover, we saw that favorable organizational treatment may create favorable conditions in order to build a positive relationship between employees and their organization. Affective ties may emerge between employees and their organization (and people working in it) because of very positive and favorable working conditions. Furthermore, literature with respect to $\mathrm{OC}$ demonstrates that $\mathrm{OC}$ is related to numerous positive work attitudes and behaviors, such as job satisfaction, work motivation, organizational citizenship behavior, and job performance (Meyer \& Herscovitch, 2001; Meyer et al., 2002). Against the backdrop of such empirical results, we depart from the idea that OC may also have positive impacts on PATC because committed employees develop more cooperative and positive behavior regarding changes in their work environment. People who are committed trust their organization and coworkers, and trust may in turn contribute to shaping positive feelings and behaviors towards organizational changes and reforms (Gould-Williams \& Davies, 2005; Lane \& Bachmann, 1998). If we take into account this underlying idea, then it is very likely that OC mediates the relationship between our independent variables and attitudes towards change. Therefore, we will also test this mediation effect by investigating whether or not OC mediates the association between the different 
independent variables under scrutiny in this article with attitudes towards change. Thus, the conceptual model of this article may be described as follows:

$* * *$ Insert Figure 1 about here $* * *$

\section{Context of the study: middle managers in Swiss public hospitals}

This study has been developed in the specific context of Swiss public hospitals, which are currently undergoing multiple reforms. We will briefly define several recent changes that have greatly affected public hospital management. First, the hospital financial system was reformed and approved in 2007 by the Swiss Parliament. The general principles of this reform aimed to clarify the financial accountability of the different actors embedded in the Swiss hospital system. Another goal was to invite these different actors (especially public hospitals) to better control their expenses by implementing new managerial practices as well as to finance the services that were actually being delivered. Swiss public hospitals are therefore now obliged to finance their activities according to a new system that attributes a precise amount for every service delivered. In other words, Swiss public hospitals have to now deal with Diagnosis Related Groups (DRG) with the result that every service is related to a precise price or rate. These rates are defined according to the average cost of each service delivered by Swiss public hospitals. The main objective of this new financial system is to harmonize the rates of the different services supplied by public hospitals throughout the country so as to bring more transparency and accountability to overall hospital costs and to facilitate benchmarking between the different hospitals.

This particular reform, among others, has had some consequences in public hospitals. First of all, they are now in direct competition with one another and hospitals that are unable to offer services according to the defined rates are subject to a deficit. The new financial system therefore incentivizes managerial actions within hospitals. Also adding to this picture is the fact that public hospitals are currently managed through contracts. This means that public hospitals, which are steered by the cantonal level of governance (Switzerland counts 26 cantons), are financed at the federal and cantonal level but their missions are stipulated in a contract they have to negotiate with their political supervision authority (at the cantonal level). These contracts prescribe the services that hospitals have to supply and they include several indicators that serve to assess whether the hospitals have concretely supplied the services for which they 
are being paid. This system leads to some important internal managerial changes such as the development of cost accounting. In other words, the reform of the financial system of public hospitals has led to important organizational changes as well as the development of new managerial practices.

In short, the specific context of Swiss public hospitals may be characterized by profound accountability, and managerial transformations. It is therefore of great interest to investigate attitudes towards change amongst public hospitals' middle managers in such a context, and to test whether organizational antecedents might explain PATC. It is extremely useful to study this specific population (middle management) because middle managers have clearly been understudied in the social science literature thus far: "Middle managers maintain a central position in organizational hierarchies, are responsible for implementing senior management strategies, and exercise control over junior staff” (Harding et al., 2014: 2). Middle managers, therefore, are important actors in organizations, as their actions are central in periods of reform because organizations cannot be formed or developed without their active engagement. They are also critical mediators between the upper echelons and the operational levels at organizations, which also contributes to the shaping of organizational strategies. Furthermore, their actions may contribute to unexpected consequences and outcomes because they continually have to interpret and adapt formal rules and strategies to the reality of the day-to-day work (Dutton et al., 1997; Mintzberg, 1989; Nonaka, 1988). Finally, according to a recent study, the identity of middle managers is very complex, as are their organizational missions since they are both the controllers and the controlled, the resisters and the resisted. In other words, middle managers control junior staff but are at the same time controlled by their supervisors (the upper echelons). They resist formal rules and strategies that they consider not applicable, but they are confronted by junior staff resistance as well: "Thus, the middle managerial identity, in incorporating controller, controlled, resister and resisted, in looking upwards to senior managers and downwards to junior staff, constitutes organizational hierarchy" (Harding et al., 2014: 20). In this sense, it is of great interest for us to identify organizational antecedents of PATC amongst middle managers who are representative of a population of workers providing important tasks for organizational functioning. 


\section{Methods}

\subsection{Sample and procedure}

To empirically test the aforementioned hypotheses, this study used a sample from five public hospitals in the French-speaking region of Switzerland. In order to optimize the response rate in our survey, we first contacted the Human Resources Department of the hospital, whereupon its executive members gave their official approval of our study. The questionnaire was developed in partnership with the leaders of the HR Department. After a test phase, an Internet link to the questionnaire was sent to all middle managers by email with a cover letter signed by the hospital officials. The employees were invited to fill out the electronic questionnaire within a month (mid-January to mid-February of 2012). A reminder was sent at the end of January to check that all employees had had the opportunity to complete it. To ensure complete privacy, answers were directly saved on a server belonging to our research team. No hospital employees had access to this data and employees were completely and transparently informed about the procedure. The announcement of these precautions had two purposes: to increase the participation rate and to function as a baseline requirement to prevent common method bias (Podsakoff et al., 2003).

Middle managers were contacted by e-mail and a total of 942 employee surveys were returned. Unfortunately, it is impossible to calculate a response rate due to the fact that we were unaware of how many employees ultimately received our questionnaire. This difficulty arose because the Internet link was sent directly by the HR departments of the investigated hospitals. Because of this missing data, we decided to delete incomplete questionnaires, bringing the final number of employee surveys in this study to 720 .

Sample characteristics are described in the Table 1 below.

\section{$* * *$ Insert Table 1 about here***}

\subsection{Measures}

The questionnaire items associated with all the measures of the study are presented in the appendix. Most of the items were measured using five-point Likert-type scales with the endpoints: 'strongly disagree' (1) and 'strongly agree' (5). Moreover, the instruments used in this research rely on self-reports. 
Attitudes towards change: We built an instrument in order to measure employees' perception with respect to recent organizational transformations and their impact on the day-to-day work of the population investigated. We have to stress here that the items are designed to measure the extent to which respondents consider the recent organizational transformations as favorable or unfavorable regarding different aspects of their job. In other words, this measure captures the perception, be it favorable or unfavorable, that respondents have concerning the impacts of recent organizational transformations on their working conditions. Therefore, this measure does not indicate positive attitudes towards change in general but rather individuals' reactions to organizational changes that have occurred. Nevertheless, these individuals' reactions to varied changes contribute to building a general feeling against reforms, which is why we called this variable PATC. Six items were used in approaching attitudes towards change within our test population (see appendix). The items for this specific measure were measured using a five-point Likert-type scale with the endpoints: «very unfavorable» (1) and « very favorable» (5). The items were ultimately averaged to create a six-item overall measure of attitudes towards change (alpha reliability of the overall scale $=0.909$ ). Organizational Commitment (OC): There are several scales for measuring OC. Furthermore, OC is composed of three different dimensions (affective, normative and rational) (Meyer \& Herscovitch, 2001; Meyer et al., 2002). For the purposes of this study, we used three items to develop OC in order to measure affective commitment. These three items were measured using a five point Likert-type scale. The coefficient of reliability for this scale is .815 . A summative index was then created for regression analysis.

Work relationships: Two variables are dedicated to social support perception. Firstly, relationships with colleagues and, secondly, relationships with supervisors. In order to measure the perceptions of our respondents in relation to work relationships, we used four items to measure satisfaction with work relationships with supervisors and two items to measure whether our respondents are satisfied with their relationships with colleagues. The coefficient of reliability for the scale with respect to relationships with supervisors is .937 . The coefficient of reliability for the scale regarding relationships with colleagues is .762. Summative indexes were then created for regression.

Stress perception: For the purposes of our study, we used the measure of perceived stress developed by Cohen et al. (Cohen et al., 1983). The great advantage of using this measurement scale is that we are able to 
reference a French version which has been used widely and has already been statistically validated (Bruchon-Schweitzer \& Dantzer, 1994). After factor analysis, we selected three items to measure this variable. The Cronbach's Alpha of this scale is .772 and summative index was then created for regression analysis.

HCHRP: In accordance with the social science literature dealing with HCHRP, several items were selected to measure the importance granted by our respondents to a certain number of HRM practices as well as characteristics of their working conditions. Although there is no clear list of such high-performance HRM practices, we rely on recent articles in order to select items with respect to six HR practices (Daley \& Vasu, 2005; Gould-Williams, 2003, 2007). The selected HR practices are: (1) formal training systems (one item); (2) internal career ladders or opportunity for professional development (one item); (3) information and communication within the organization (two items; Cronbach's Alpha = .748); (4) employee voice and participation (two items; Cronbach's Alpha = .755); (5) compensation (one item); (6) employment security (one item). Several of these HRM practices are measured with one item. As a general rule, constructs formulated from multiple items are preferable, particularly for the purposes of validity and reliability. However, because the main objective of this study is to assess the effect of several HRM practices on attitudes towards change, it was feasible to proceed this way. Nevertheless, the fact that single items were used to measure perceptions toward HRM practices can be noted as a limitation of this study. It is also important to stress that the measures of HCHRP used in our questionnaire rely on respondents' perceptions of HCHRP rather than organizational policy or practice. Indeed, in this study, we are mainly interested in the HR practices that are actually experienced by our respondents rather than those that might be suggested by HR policies formally developed by the organization. This strategy is in line with a growing number of other studies with respect to HCHRP (Alfes et al., 2012; Gould-Williams et al., 2013; Schott \& Pronk, 2014).

Controls: Previous research has shown that employees' age, gender, and organizational tenure are related to many work outcomes such as organizational commitment (Meyer \& Allen, 1997; Meyer et al., 2002). Therefore, these variables were included in our analyses in order to exclude alternative explanations from our findings. 


\subsection{Statistical analysis}

Prior to assessing the reliability of our different variables, two other indicators were used for testing the condition of the dataset. The data was reviewed to ensure that the assumptions of normality were upheld. Finally, the dataset was examined to determine if multicollinearity was an issue (Hayduk, 1987). The tolerance and VIF scores of our data also fell within the acceptable range for all the variables. On the basis of such evidence, we can conclude that the dataset was in good condition.

In order to test our different hypotheses, we performed ordinary least square (OLS) regression analysis using SPSS 21. The mediating effect of $\mathrm{OC}$ is assessed by applying a hierarchical regression analysis according to the rules developed by Baron and Kenny (Baron \& Kenny, 1986): "These rules state that mediation is shown when: a) there are significant correlations between the independent variable and the presumed mediator (path a); b) the presumed mediator affects the dependent variable (path b); c) differences in the independent variable are significantly related to differences in the dependent variable (path c); and finally, when path a and path $\mathrm{b}$ are controlled, the previously significant relationship between independent and dependent variable (path c) vanishes" (Schott \& Pronk, 2014: 14).

As complete mediation is unlikely to be noted in this kind of research (see for instance: Vandenabeele, 2009), we pay particular attention to the partial mediation effect. The "Sobel test" is a statistical procedure that may be used to test such a partial mediation effect (Preacher \& Leonardelli, 2001), resulting in a Zscore (a Z-score $>1.95$ can be considered as the cutoff criteria for partial mediation).

\section{Results}

Table 2 summarizes Pearson's correlation coefficients between all variables of this study. Firstly, we can report strong correlations between PATC and all our independent variables and most of them also correlate with OC, indicating that we cannot reject the hypothesis of mediation. Secondly, correlations between the predictor variables are weak, indicating that multicollinearity is not a concern in the present study.

\section{$* * *$ Insert Table 2 about here $* * *$}

Table 3-4 reports the results of the different regression analyses in order to test relationships between independent variables and the mediator (path a) and between independent variables and the dependent 
variable (path c). According to Table 2, we already know that the mediator (OC) is strongly correlated $(\mathrm{r}=$ $.393 ; \mathrm{p}<.000$ ) to attitudes towards change (path b). Finally, a final regression is performed in which the mediator variable is integrated into the analysis of the relationship between independent variables and the dependent variable in order to test for mediation effects. With respect to the first regression analysis (path a), it is possible to note that several variables are significantly correlated to OC. Age, organizational tenure, and gender are significantly related to OC, confirming previous research demonstrating that older employees, as well as employees benefitting from a longer organizational tenure, are more likely to develop a stronger commitment to their organization. In this study, men also declare a stronger organizational commitment compared to their female counterparts. Turning to the independent variables, we can see that four of them are related to OC: information and communication $(\mathrm{r}=.159 ; \mathrm{p}<.000)$; employee voice and participation $(\mathrm{r}=.132 ; \mathrm{p}<.005)$; work relationships with colleagues $(\mathrm{r}=.073 ; \mathrm{p}<.05)$; work relationships with superiors $(\mathrm{r}=.207 ; \mathrm{p}<.000)$. All the other independent variables included in the equation are not significantly related to OC (formal training system; internal career ladders or opportunity for professional development; compensation; employment security; work-life balance; perceived stress). Therefore those latter variables will not be integrated into our mediation analyses. Furthermore, the analysis shows that $24.1 \%$ (adj. $\mathrm{R}^{2}=.241$ ) of the variation of $\mathrm{OC}$ can be explained by the variation in the independent variables.

\section{$* * *$ Insert Table 3 about here $* * *$}

If we turn now to the results with respect to antecedents of attitudes towards change (path c, Table 4), we can note, firstly, that older employees reported more PATC compared to their younger counterparts $(\mathrm{r}=$ $.065 ; \mathrm{p}<.05)$. Gender and organizational tenure are not significantly related to attitudes towards change. Moreover, six out of ten of our independent variables are significantly associated with PATC: information and communication $(\mathrm{r}=.207 ; \mathrm{p}<.000)$; employee voice and participation $(\mathrm{r}=.157 ; \mathrm{p}<.000)$; work relationships with supervisors $(\mathrm{r}=.125 ; \mathrm{p}<005)$; work relationships with colleagues $(\mathrm{r}=.117 ; \mathrm{p}<.000)$; work-life balance $(\mathrm{r}=.115 ; \mathrm{p}<.005)$. Finally, stress perception, as expected, is significantly but negatively related to PATC $(r=-.122 ; \mathrm{p}<.000)$. All the independent variables explain $44.8 \%\left(\operatorname{adj} \mathrm{R}^{2}=.448\right)$ of the variation of our dependent variable. 


\section{$* * *$ Insert Table 4 about here***}

As recommended by Baron and Kenny (1986), a new regression analysis should be developed integrating the mediator variable into the analysis of the relationship between the independent and the dependent variable in order to test for possible mediation effects. Therefore, only the variables that are significantly related to PATC and OC according to previous analyses have been included in this supplementary regression analysis (information and communication; employee voice and participation; work relationships with colleagues; work relationships with supervisors).

\section{$* * *$ Insert Table 5 about here $* * *$}

With respect to this new regression analysis, it may be noted that after including OC, the strong effects of the four independent variables on PATC have been reduced. In order to verify whether this reduction in the Betas is due to partial mediation effects, we have to perform a Sobel test (see Table 6) (Vandenabeele, 2009). As regards the results obtained via the Sobel test, we may note that OC partially mediates the relationship between the following variables and PATC: information and communication $(Z=3.31 ; \mathrm{p}<$ $.000)$; employee voice and participation $(Z=2.71 ; p<.05)$; work relationship with supervisors $(Z=4.93$; $\mathrm{p}<.000)$. On the contrary, no mediation effect can be detected with respect to work relationships with colleagues $(Z=1.57 ; \mathrm{p}>.10)$.

$* * *$ Insert Table 6 about here***

Based on these results we can now summarize our findings:

\begin{tabular}{|l|l|l|}
\hline Hypotheses supported by our data & Hypotheses not supported by our & Partial mediations supported by \\
(antecedents of PATC) & data (antecedents not related to & our data: \\
\hline
\end{tabular}




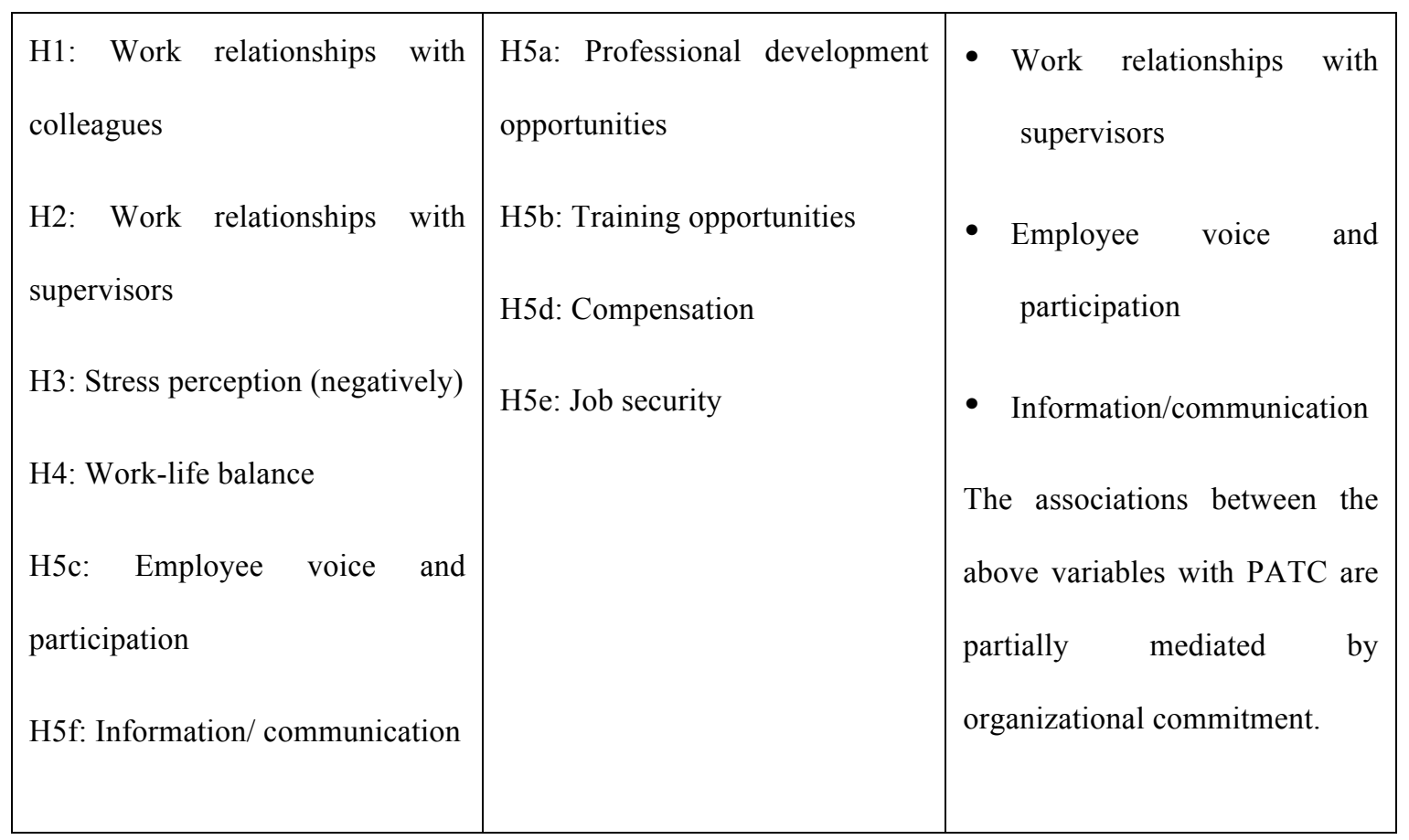

\section{Discussion}

The findings show that PATC within a population of public middle managers is directly influenced by several distinctive antecedents. First, social support is very important in creating a work atmosphere that can generate PATC. Indeed, satisfaction in relationships with colleagues (H1) and supervisors (H2) is significantly and positively related to PATC. Furthermore, we also found that stress perception (H3) is negatively and significantly associated with PATC. This specific finding is of particular importance because it indicates that attitudes towards change are also a question of personal and organizational resources. In a nutshell, when job demands exceed job resources, employees will report higher levels of stress. The latter will be negatively associated with PATC and are therefore likely to limit the commitment of middle managers in change management. Managing under stress is therefore not favorable to organizational change and reforms. (Noblet et al., 2006; Schaufeli \& Bakker, 2004 ; Bakker \& Demerouti, 2007; Demerouti et al., 2001; Van den Broeck et al., 2008). Work-life balance (H4) is also associated with PATC in this present study, underlining the importance of a healthy balance between work and private life in the development of a positive attitude towards organizational changes and reforms. This finding is in line 
with previous research demonstrating that middle managers may suffer from the colonization of all areas of their lives by professional issues (Thomas \& Linstead, 2002).

We also found that two human resources practices are positively related to PATC (H5c and H5f). Information and communication, as well as employee voice and participation, are directly related to PATC. We can also note that these results underline the centrality of social exchange mechanisms in organizations. The more middle managers feel that they benefit from supportive organizational and social mechanisms, the more they will report PATC. This finding also holds true for OC. Indeed, our findings show that work relationships with colleagues and supervisors, as well as employee voice and participation, and information/communication, might be considered as antecedents of OC. Organizational and social support facilitate the development of affective ties between middle managers and their organization. In this sense, middle managers are more willing to be committed to their organization if they perceive that they are working in a supportive environment. It is also worth noting that the association between three out of four variables (work relationships with supervisors; employee voice and participation; information/communication) with PATC is partially mediated by OC. All these results provide strong theoretical support for social exchange theory and more specifically for organizational support theory.

Finally, it is also interesting to note that variables that are positively related to PATC may be considered as non-monetary organizational incentives (work relationships; employee voice and participation; information/communication; work-life balance). Furthermore, almost all of these variables promote intrinsic rather than extrinsic work incentives (except for work-life balance). These findings are in line with previous research showing that public employees tend to prefer intrinsic non-monetary work opportunities over monetary and extrinsic ones (Bright, 2009; Giauque et al., 2013a). In this sense, we can suggest that PATC is more of a qualitative and subjective question than a quantitative and objective one. In other words, PATC depends more on perceived organizational support than material and extrinsic rewards. This last remark, however, deserves further investigation.

\section{Conclusions}

Based on the data we have presented, it can be concluded that perceived social support (perceived work relationships with colleagues and supervisors) and perceived organizational support (more specifically, 
employee voice and participation, information/communication, and work-life balance) play a central role in the development of PATC. Non-monetary intrinsic work opportunities have a greater impact on PATC than monetary extrinsic work opportunities. In this study, we have found that compensation, job security, professional development opportunities, and training opportunities are not associated with PATC. For practitioners, these findings indicate that it is most likely more efficient to propose intrinsic non-monetary work opportunities in order to support middle managers facing a context of organizational change and reform.

Furthermore, there appears to be considerable value in viewing PATC through the lens of social exchange theory and perceived organizational support theory. Middle managers will report higher levels of organizational commitment and will develop PATC if they perceive that their organization gives them supportive work opportunities. Such perceptions will increase middle managers' commitment to their organization and they will face organizational reforms and changes with a more positive attitude.

Finally, our findings also confirm the results of previous research showing that stress perception is negatively related to numerous work outcomes. In all cases, our findings show that stress perception (the perception that work demands exceed work resources in the face of professional changes) is negatively related to PATC. In this sense, it is crucial to ensure adequate resources for middle managers so that they can tackle organizational reforms and changes. Our results also show that work-life balance is an important antecedent of PATC for public middle managers in Swiss hospitals. Therefore, it is worth developing such work-life balance opportunities in order to create favorable work conditions for middle managers. This research provides valuable lessons regarding antecedents of PATC in public organizations that are confronted with numerous financial, and organizational reforms. Nevertheless, issues related to change perception among public employees, and middle managers more precisely, deserve further research in order to better understand individual and organizational antecedents of PATC, as well as the relationships between PATC and work outcomes. 


\section{Limitations and future research}

As with all research, this study encountered several limitations. The first concerns common method bias. Because our respondents were asked to report predictors and outcome variables in the same online questionnaire, this survey strategy might inflate reported effect sizes (Podsakoff et al., 2003).

Secondly, despite the fact that all of our independent variables explain more than $40 \%$ of the variance of PATC, this study may ignore important variables that would offer additional explanations for attitudes towards change among a population of middle managers. For instance, the goals set in the reforms and organizational changes may have an impact on PATC as well. In this sense, it could be useful to take into account the goal-setting theory in order to investigate whether characteristics or properties of goals related to organizational reforms may have an impact on PATC. New research must therefore be undertaken in order to better identify and assess the predictors of such attitudes.

We also must note that our findings are based on a sample of Swiss middle managers. It is likely that the unique characteristics of such public employees may have an impact on the results of this research. The organizational features of Swiss hospitals, as well as the fact that they are mostly confronted with operational activities (the implementation of public policies) rather than strategic ones (the definition of public policies), may also impact our findings. For this reason, it would be beneficial in a comparative sense to replicate this study with employees working in different professional settings.

Finally, concerning methodological issues, it would be of great interest to complete our statistical survey with a qualitative investigation so as to better understand the meaning that middle managers assign to their working experiences, whether they are satisfactory or unsatisfactory. Despite these limitations, this article provides topical and tangible empirical findings with respect to the antecedents of attitudes towards change among a population of middle managers.

\section{Acknowledgement:}

This article is part of a broader research project ( $n^{\circ}$ 13DPD6_134764/1) financed by the Swiss National Science Foundation (www.snf.ch). 


\section{REFERENCES}

Alfes, K., Shantz, A., \& Truss, C. (2012). The link between perceived HRM practices, performance and well-being: the moderating effect of trust in the employer. Human Resource Management Journal, 22(4), 409-427.

Andriopoulos, C. (2001). Determinants of organizational creativity: a literature review. Management Decision, 39, 834-840.

Argyris, C., \& Schön, D. (1996). Organizational Learning II: Theory, method and practice. Menlo Park California: Addison-Wesley.

Aselage, J., \& Eisenberger, R. (2003). Perceived organizational support and psychological contracts: a theoretical integration. Journal of Organizational Behavior, 24(5), 491-509.

Bakker, A. B., \& Demerouti, E. (2007). The Job Demands-Resources model: State of the art. Journal of Managerial Psychology, 22, 309-328.

Baron, R., \& Kenny, D. (1986). The moderator-mediator variable distinction in social psychological research: Conceptual, strategic, and statistical considerations. Journal of personality and social psychology, 51(6), 1173-1182.

Blau, P. M. (1964). Exchange and power in social life. New York: Wiley.

Boselie, P. (2010). High performance work practices in the health care sector: A Dutch case study. International Journal of Manpower, 31(1), 42-58.

Bright, L. (2009). Why Do Public Employees Desire Intrinsic Nonmonetary Opportunities? Public Personnel Management, 38(3), 15-37.

Bruchon-Schweitzer, M., \& Dantzer, R. (1994). Introduction à la psychologie de la santé. Paris: PUF.

Caillé, A. (1997). Don, association et solidarité. Revue internationale de l'économie sociale(265), 49-57.

Caldwell, S. D. (2011). Bidirectional Relationships Between Employee Fit and Organizational Change. Journal of Change Management, 11(4), 401-419.

Carpenter, D. P. (2001). The Forging of Bureaucratic Autonomy. Princeton, NJ: Princeton University Press.

Chan Su Jung, \& Rainey, H. G. (2011). Organizational Goal Characteristics and Public Duty Motivation in U.S. Federal Agencies. Review of Public Personnel Administration, 31(1), 28-47.

Chih, W.-H. W., Yang, F.-H., \& Chang, C.-K. (2012). The Study of the Antecedents and Outcomes of Attitude Toward Organizational Change. Public Personnel Management, 41(4), 597-617.

Clary, B., Eberstein, S., \& Harlor, S. (2000). Organizational Change Issues in Performance Government. The Case of Contracting. Public Productivity \& Management Review, 23(3), 282 -296.

Cohen, S., Kamarck, T., \& Mermelstein, R. (1983). A Global Measure of Perceived Stress. Journal of Health and Social Behavior, 24(4), 385-396.

Daley, D. M., \& Vasu, M. L. (2005). Supervisory perceptions of the impact of public sector personnel practices on the achievement of multiple goals. Putting the strategic into human resource management. American Review of Public Administration, 35(2), 157-167.

Delaney, J. T., \& Huselid, M. A. (1996). The impact of human resource management practices on perceptions of organizational performance. Academy of Management Journal, 39, 949-969.

Demerouti, E., Bakker, A. B., Nachreiner, F., \& Schaufeli, W. B. (2001). The Job Demands-Resources model of burnout. Journal of Applied Psychology, 51, 115-134.

Dupuy, F. (2004). Sociologie du changement : pourquoi et comment changer les organisations. Paris: Dunod. 
Dupuy, F. (2011). Lost in management. La vie quotidienne des entreprises au XXIe siècle. Paris: Editions du Seuil.

Dutton, J. E., Ashford, S. J., Wierba, E. E., O'Neil, R., \& Hayes, E. (1997). Reading the Wind: How Middle Managers Assess the Context for Issue Selling to Top Managers. Strategic Management Journal, 13(5), 153-167.

Eby, L., Adams, D., Russell, J., \& Gaby, S. (2000). Perceptions of organizational readiness for change: factors related to employee's reactions to the implementation of team-based selling. Human Relations, 53(3), 419-428.

Eisenberger, R., Fasolo, P., \& Davis-LaMastro, V. (1990). Perceived organizational support and employee diligence, commitment, and innovation. Journal of Applied Psychology, 75, 51-59.

Fisher, C., Harris, L., Kirk, S., Leopold, J., \& Leverment, Y. (2004). The Dynamics of Modernization and Job Satisfaction in the British National Health Service. Review of Public Personnel Administration, 24(4), 304-318.

Ford, J., \& Collinson, D. (2011). In Search of the Perfect Manager? Work-Life Balance and Managerial Work. Work, Employment \& Society, 25(2), 257-273.

Ford, J., \& Harding, N. (2003). Invoking Satan or the Ethics of the Employment Contract. Journal of Management Studies, 40(5), 1131-1150.

Giauque, D., Anderfuhren-Biget, S., \& Varone, F. (2013a). HRM Practices, Intrinsic Motivators, and Organizational Performance in the Public Sector. Public Personnel Management, Published Online.

Giauque, D., Anderfuhren-Biget, S., \& Varone, F. (2013b). Stress Perception in Public Organisations: Expanding the Job Demands-Job Resources Model by Including Public Service Motivation. Review of Public Personnel Administration, 33(1), 58-83.

Giauque, D., Resenterra, F., \& Siggen, M. (2014). Antecedents of Job Satisfaction, Organizational Commitment and Stress in a Public Hospital: a P-E Fit Perspective. Public Organization Review, 14(2), 201-228.

Gilmore, T. N., \& Barnett, C. (1992). Designing the social architecture of participation in large groups to effect organizational change. The Journal of Applied Behavioral Science, 28(4), 534-548.

Gould-Williams, J. (2003). The importance of HR practices and workplace trust in achieving superior performance: a study of public-sector organizations. International Journal of Human Resource Management, 14(1), 28-54.

Gould-Williams, J. (2007). HR practices, organizational climate and employee outcomes: evaluating social exchange relationships in local government. International Journal of Human Resource Management, 18(9), 1627-1647.

Gould-Williams, J., \& Davies, F. (2005). Using social exchange theory to predict the effects of HRM practice on employee outcomes. Public Management Review, 7(1), 1-24.

Gould-Williams, J. S., Bottomley, P., Redman, T. O. M., Snape, E. D., Bishop, D. J., Limpanitgul, T., et al. (2013). Civic Duty and Employee Outcomes: Do High Commitment Human Resource Practices and Work Overload Matter? Public Administration, Published Online.

Harding, N., Lee, H., \& Ford, J. (2014). Who is 'the middle manager'? Human Relations.

Hayduk, L. (1987). Structural equation modeling with LISREL: Essentials and advances (Vol. 13). Baltimore: John Hopkins University Press.

Heckscher, C., \& Donnellon, A. (Eds.). (1994). The Post-bureaucratic Organization : New Perspectives on Organizational Change. Londres: Sage.

Homans, G. C. (1961). Social behavior. New York: Harcourt, Brace, and World. 
Huselid, M. A. (1995). The Impact of Human Resource Management Practices on Turnover, Productivity, and Corporate Financial Performance. Academy of Management Journal, 38(3), 635-672.

Jimenez-Jimenez, D., \& Sanz-Valle, R. (2005). Innovation and human resource management fit: an empirical study. International Journal of Manpower, 26(4), 364-381.

Jones, G. R. (2007). Organizational Theory, Design, and Change. Upper Saddle River: Pearson Prentice Hall.

Kalleberg, A. L., Marsden, P. V., Reynolds, J., \& Knoke, D. (2006). Beyond Profit? Sectoral Differences in High-Performance Work Practices. Work and Occupations, 33(3), 271-302.

Karasek, R., \& Theorell, T. (1990). Healthy work: stress, productivity, and the reconstruction of working life. New York: Basic Books.

Kirkpatrick, I., Jespersen, P. K., Dent, M., \& Neogy, I. (2009). Medicine and Management in a Comparative Perspective: The Case of Denmark and England. Sociology of Health \& Illness, 31(5), 642-658.

Kotter, J. P. (1996). Leading change, why transformation efforts fail. Harvard, MA: HBS Press.

Kuhlmann, E., Allsop, J., \& Saks, M. (2009). Professional Governance and Public Control: A Comparison of Healthcare in the United Kingdom and Germany. Current Sociology, 57(4), 511-528.

Kuipers, B. S., Higgs, M., Kickert, W., Tummers, L., Grandia, J., \& Van Der Voet, J. (2014). The Management of Change in Public Organizations: A Literature Review. Public Administration, 92(1), 1-20.

Lane, C., \& Bachmann, R. (Eds.). (1998). Trust Within and Between Organizations. Conceptual Issues and Empirical Applications. New York: Oxford University Press.

Lindorff, M. (2009). We're Not all Happy Yet: Attitudes to Work, Leadership, and High Performance Work Practices among Managers in the Public Sector. The Australian Journal of Public Administration, 68(4), 429-445.

Locke, E. A., \& Latham, G. P. (2002). Building a Practically Useful Theory of Goal Setting and Task Motivation. American Psychologist, 57(9), 705-717.

Locke, E. A., \& Latham, G. P. (2006). New Directions in Goal-Setting Theory. Current Directions in Psychological Science, 15(5), 265-268.

MacDuffie, J. P. (1995). Human resource bundles and manufacturing performance: organizational logic and flexible production systems in the world auto industry. Industrial \& Labor Relations Review, 48(2), 197-221.

March, J. G., \& Simon, H. (1964). Les organisations. Problèmes psycho-sociologiques. Paris: Dunod.

Mauss, M. (1985 [1950]). Essai sur le don, forme et raison de l'échange dans les sociétés archaïques. In M. Mauss (Ed.), Sociologie et anthropologie (pp. 145-279). Paris: PUF.

Messersmith, J. G., Patel, P. C., Lepak, D. P., \& Gould-Williams, J. S. (2011). Unlocking the black box: Exploring the link between high-performance work systems and performance. Journal of Applied Psychology, 96(6), 1105-1118.

Meyer, J. P., \& Allen, N. J. (1997). Commitment in the Workplace: Theory, research, and application. Newbury Park, CA: Sage.

Meyer, J. P., \& Herscovitch, L. (2001). Commitment in the Workplace: Toward a general model. Human Resource Management Review(11), 299-326.

Meyer, J. P., Stanley, D. J., Herscovitch, L., \& Topolnytsky, L. (2002). Affective, continuance, and normative commitment to the organization: A meta-analysis of antecedents, correlates, and consequences. Journal of Vocational Behavior, 61, 20-52. 
Mintzberg, H. (1989). Mintzberg on Management. New York: Free Press.

Noblet, A., Rodwell, J., \& McWilliams, J. (2006). Organizational Change in the Public Sector: Augmenting the Demand Control Model to Predict Employee Outcomes under New Public Management. Work \& Stress, 20(4), 335-352.

Noblet, A. J., \& Rodwell, J. J. (2008). Integrating job stress and social exchange theories to predict employee strain in reformed public sector contexts. Journal of Public Administration Research and Theory, 19, 555-578.

Nonaka, I. (1988). Toward Middle-Up-Down Management: Accelerating Information Creation. Sloan Management Review, 29, 9-18.

Podsakoff, P. M., MacKenzie, S. B., Jeong-Yeon, L., \& Podsakoff, N. P. (2003). Common Method Biases in Behavioral Research: A Critical Review of the Literature and Recommended Remedies. [Article]. Journal of Applied Psychology, 88(5), 879.

Preacher, K. J., \& Leonardelli, G. J. (2001). Calculation for the Sobel Test: An Interactive Calculation Tool for Mediation Tests. from: http://www.psych.ku.edu/preacher/sobel/sobel.htm.

Rhoades, L., Eisenberger, R., \& Armeli, S. (2001). Affective commitment to the organization: the contribution of perceived organizational support. Journal of Applied Psychology, 86(5), 825-836.

Richardsen, A. M., Burke, R. J., \& Leiter, M. P. (1992). Occupational Demands, Psychological Burnout and Anxiety among Hospital Personnel in Norway. Anxiety Stress and Coping, 5(1), 55-68.

Rourke, F. E. (1984). Bureaucracy, Politics, and Public Policy. New York, NY: Little, Brown.

Rousseau, D. (1995). Psychological Contracts in Organizations. Understanding Written and Unwritten Agreements. London: Sage.

Rousseau, D. M. (1997). Organizational Behavior in the New Organizational Era. Annual Review of Psychology(48).

Rush, M., Schoel, W., \& Barnard, S. (1995). Psychological resiliency in the public sector: "hardiness" and pressure for change. Journal of Vocational Behavior, 46(1), 17-39.

Schaufeli, W. B., \& Bakker, A. B. (2004). Job demands, job resources, and their relationship with burnout and engagement: a multi-sample study. Journal of Organizational Behavior, 25, 293-315.

Schott, C., \& Pronk, J. (2014). Investigating and explaining organizational antecedents of PSM. Evidencebased HRM: a Global Forum for Empirical Scholarship, 2(1), Published Online.

Shore, L. M., \& Coyle-Shapiro, J. A.-M. (2003). New developments in the employee-organization relationship. Journal of Organizational Behavior, 24(5), 443-450.

Snell, S., \& Dean, J. A. (1992). Integrated manufacturing and human resource management: a human capital perspective. Academy of Management Journal, 35, 467-504.

Spirig, R., Spichiger, E., Martin, J. S., Frei, I. A., Müller, M., \& Kleinknecht, M. (2014). Monitoring the impact of the DRG payment system on nursing service context factors in Swiss acute care hospitals: Study protocol. German Medical Science, 12, 1-13.

Taylor, S., Levy, O., Boyacigiller, N. A., \& Beechler, S. (2008). Employee commitment in MNCs: HRM and top management orientations. The International Journal of Human Resource Management, 19(4), 501-527.

Thomas, R., \& Linstead, A. (2002). Losing the Plot? Middle Managers and Identity. Organization, 9(1), 71-93.

Vakola, M., \& Nikolaou, I. (2005). Attitudes towards organizational change. What is the role of employees' stress and commitment? Employee Relations, 27(2), 160-174. 
Van den Broeck, A., Vansteenkiste, M., De Witte, H., \& Lens, W. (2008). Explaining the relationships between job characteristics, burnout, and engagement: The role of basic psychological need satisfaction. Work and Stress, 22(3), 277-294.

Vandenabeele, W. (2009). The mediating effect of job satisfaction and organizational commitment on selfreported performance: more robust evidence of the PSM-performance relationship. International Review of Administrative Sciences, 75(1), 11-34.

Walton, R. E. (1985). From control to commitment in the workplace. Harvard Business Review, 63(2), 7784.

Whitener, E. M. (2001). Do "high commitment" human resource practices affect employee commitment? A cross-level analysis using hierarchical linear model. Journal of Management, 27(5), 515-535.

Whittle, A. (2008). From Flexibility to Work-Life Balance: Exploring the Changing Discourses of Management Consultants. Organization, 15(4), 513-534.

Wood, S., \& Menezes, L. (1998). High commitment management in the U.K.: evidence from the Workplace Industrial Relations Survey and Employers' Manpower and Skills Practices Survey. Human Relations, 51, 485-515.

Wooldridge, E. (2001). Understanding the psychological contract in the public sector. London: Public Policy and Management Association.

Wright, B. E. (2004). The Role of Work Context in Work Motivation: A Public Sector Application of Goal and Social Cognitive Theories. Journal of Public Administration Research and Theory, 14(1), 5978.

Youndt, M., Snell, S., Dean, J. A., \& Lepak, D. (1996). Human resource management, manufacturing strategy, and firm performance. Academy of Management Journal, 39, 836-866.

Yu, M.-C. (2009). Employees' Perception of Organizational Change: The Mediating Effects of Stress Management Strategies. Public Personnel Management, 38(1), 17-32. 
Figures, Tables and Appendix:

Figure 1: conceptual model and relationships between variables

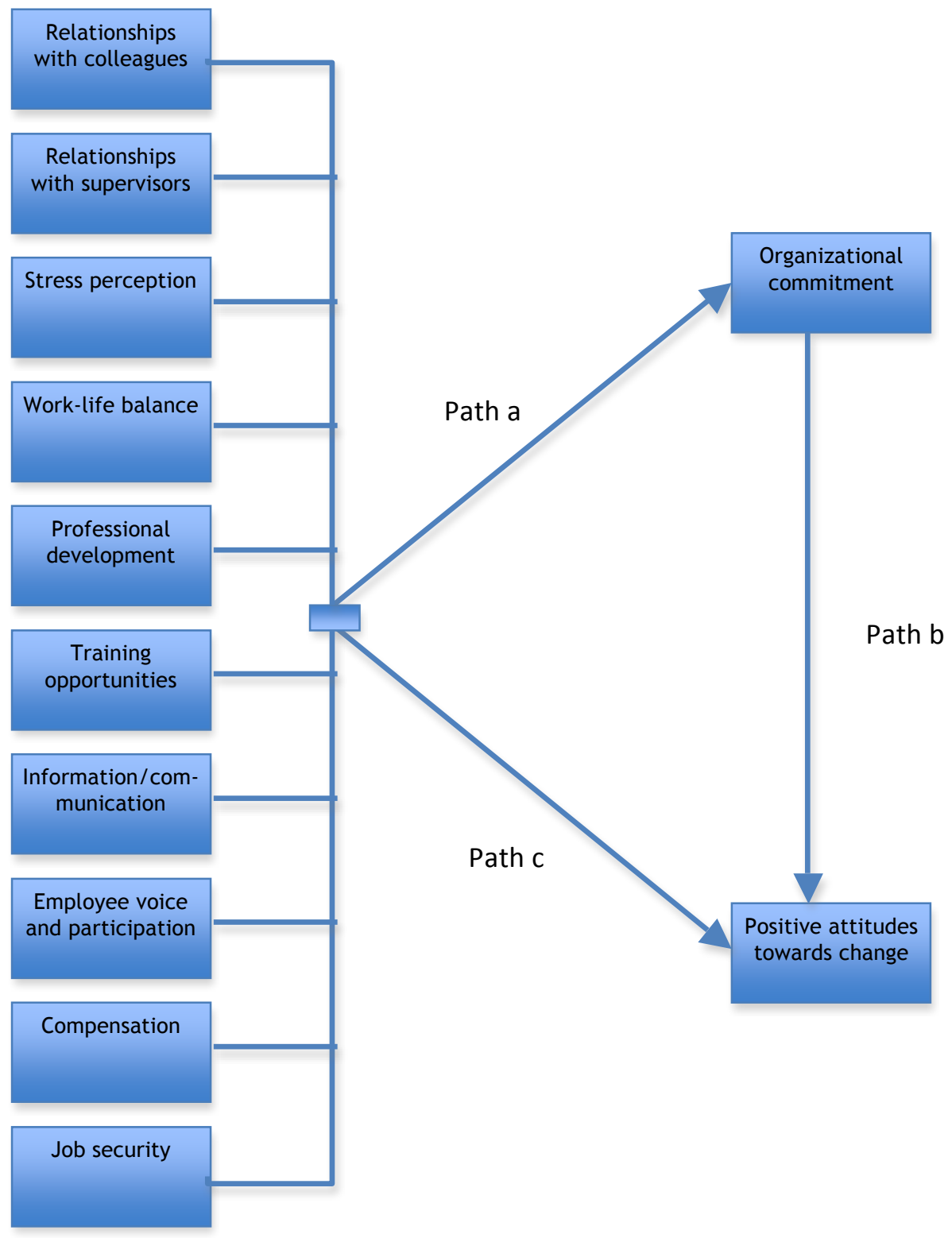


Table 1: sample characteristics

\begin{tabular}{|l|l|}
\hline Variables: & Sample characteristics : \\
\hline Gender: & $45 \%$ women \\
& $55 \%$ men \\
\hline Age categories: & 20 years old and less: $0.1 \%$ \\
& $21-30: 1.5 \%$ \\
& $31-40: 17.7 \%$ \\
& $41-50: 39 \%$ \\
& $51-60: 36 \%$ \\
& 61 and more: $5.7 \%$ \\
\hline Function categories: & Other managers: $32.4 \%$ \\
& Administrative managers: $9.9 \%$ \\
& Nursing managers: $33.7 \%$ \\
& Medical managers: $24 \%$ \\
\hline Professional tenure: & Less than one year: $2.1 \%$ \\
& $1-2: 2.9 \%$ \\
& $3-5: 6.1 \%$ \\
& $6-10: 9.8 \%$ \\
& $11-15: 17.6 \%$ \\
& $16-24: 32.4 \%$ \\
& 25 and more: $29.2 \%$ \\
\hline Functional tenure: & Less than one year: $3.3 \%$ \\
& $1-2: 7.8 \%$ \\
& $3-5: 17.9 \%$ \\
& $6-10: 20.2 \%$ \\
& $11-15: 23.1 \%$ \\
& $16-24: 20.6 \%$ \\
& 25 and more: $7.1 \%$ \\
\hline & Less than one year: $1.4 \%$ \\
& $1-2: 2.1 \%$ \\
& $3-5: 5.5 \%$ \\
& $6-10: 13.9 \%$ \\
& $11-15: 19.2 \%$ \\
& $16-24: 31.3 \%$ \\
& 25 and more: $26.5 \%$ \\
\hline & \\
&
\end{tabular}


Table 2: bivariate correlations between the study's variables

\begin{tabular}{|c|c|c|c|c|c|c|c|c|c|c|c|c|c|c|c|}
\hline & 1 & 2 & 3 & 4 & 5 & 6 & 7 & 8 & 9 & 10 & 11 & 12 & 13 & 14 & 15 \\
\hline PATC & 1 & & & & & & & & & & & & & & \\
\hline $\mathrm{OC}$ & $.393^{* *}$ & 1 & & & & & & & & & & & & & \\
\hline Gender & .041 & $.091^{*}$ & 1 & & & & & & & & & & & & \\
\hline Age & $.090^{*}$ & $.178^{* *}$ & $.073^{*}$ & 1 & & & & & & & & & & & \\
\hline Org. tenure & . 044 & .165** & . 046 & $.484 * *$ & 1 & & & & & & & & & & \\
\hline $\begin{array}{l}\text { Training } \\
\text { opportunities }\end{array}$ & .299** & . $174^{* * *}$ & .061 & -.014 & . 027 & 1 & & & & & & & & & \\
\hline $\begin{array}{l}\text { Professional } \\
\text { development }\end{array}$ & $.408^{* * *}$ & $.266^{* *}$ & -.014 & -.068 & .015 & .457 ** & 1 & & & & & & & & \\
\hline Information & $.530^{* * *}$ & $.385^{* * *}$ & . 022 & $.073^{*}$ & .059 & $.307 * *$ & $.388^{* *}$ & 1 & & & & & & & \\
\hline $\begin{array}{l}\text { Voice and } \\
\text { participation }\end{array}$ & $.528^{* * *}$ & $.375^{* *}$ & .035 & .048 & .033 & $.358^{* * *}$ & $.493^{* *}$ & $.575^{* *}$ & 1 & & & & & & \\
\hline Remuneration & $.361^{* *}$ & $.227^{* * *}$ & .057 & . $190^{* *}$ & $.155^{* *}$ & $.308^{* *}$ & $.434^{* *}$ & $.333^{* *}$ & $.316^{* *}$ & 1 & & & & & \\
\hline Job security & $.342^{* *}$ & $.219^{* * *}$ & . 007 & .013 & -.028 & $.291^{* *}$ & $.297 * *$ & $.316^{* *}$ & $.343^{* *}$ & $.233^{* * *}$ & 1 & & & & \\
\hline $\begin{array}{l}\text { Work-life } \\
\text { balance }\end{array}$ & . $377 * *$ & . $175^{* * *}$ & -.053 & -.005 & $-.128 * *$ & $.182^{* *}$ & $.210^{* *}$ & $.278^{* *}$ & $.261^{* *}$ & $.208^{* *}$ & $.402^{* *}$ & 1 & & & \\
\hline $\begin{array}{l}\text { Relationships } \\
\text { colleagues }\end{array}$ & $.410^{* *}$ & $.278^{* *}$ & .004 & .050 & $.078^{*}$ & . $196^{* *}$ & $.325^{* *}$ & $.354^{* *}$ & $.336^{* *}$ & $.292^{* *}$ & $.249 * *$ & $.243^{* *}$ & 1 & & \\
\hline $\begin{array}{l}\text { Relationships } \\
\text { supervisors }\end{array}$ & $.484^{* *}$ & $.377^{* *}$ & -.055 & -.044 & . 027 & $.327^{* *}$ & $.477^{* *}$ & $.435^{* *}$ & $.557^{* *}$ & $.287^{* *}$ & $.394^{* *}$ & $.320^{* *}$ & $.394^{* *}$ & 1 & \\
\hline Stress & $-.441^{* *}$ & -. $188^{* * *}$ & .014 & $-.072^{*}$ & .001 & $-.208^{* *}$ & $-280^{* *}$ & $-.338^{* *}$ & $-.380^{* *}$ & $-.288^{* *}$ & $-.280^{* * *}$ & $-.495 * *$ & $-346^{* *}$ & $-.365^{* *}$ & 1 \\
\hline
\end{tabular}

$\mathrm{p}<.05 * / \mathrm{p}<.01 * *$ 
Table 3: Hierarchical regression analyses for variables predicting OC (path a)

\begin{tabular}{|c|c|c|c|}
\hline & & Model 1: & Model 2: \\
\hline & & $\begin{array}{l}\text { B } \\
\text { (Std. Error) }\end{array}$ & $\begin{array}{l}\text { B } \\
\text { (Std. Error) }\end{array}$ \\
\hline \multirow[t]{3}{*}{$\begin{array}{l}\text { Step 1: Control } \\
\text { variables }\end{array}$} & Gender & $\begin{array}{l}.069 \\
(.070)\end{array}$ & $\begin{array}{l}.081 * \\
(.063)\end{array}$ \\
\hline & Age & $\begin{array}{l}.110^{* *} \\
(.045)\end{array}$ & $\begin{array}{l}.118^{* *} \\
(.042)\end{array}$ \\
\hline & Org. tenure & $\begin{array}{l}.106^{*} \\
(.029)\end{array}$ & $\begin{array}{l}.085^{*} \\
(.026)\end{array}$ \\
\hline \multirow[t]{15}{*}{ Step 2: Independent variables } & Training & & $\begin{array}{l}-.008 \\
(.038)\end{array}$ \\
\hline & Prof. dev. & & $\begin{array}{l}.031 \\
(.037)\end{array}$ \\
\hline & Information & & $\begin{array}{l}.159 * * * \\
(.047)\end{array}$ \\
\hline & Participation & & $\begin{array}{l}.132 * * \\
(.048)\end{array}$ \\
\hline & Remuneration & & $\begin{array}{l}-.004 \\
(.035)\end{array}$ \\
\hline & Job security & & $\begin{array}{l}.012 \\
(.042)\end{array}$ \\
\hline & Work-life balance & & $\begin{array}{l}.049 \\
(.035)\end{array}$ \\
\hline & Relationships with colleagues & & $\begin{array}{l}.073^{*} \\
(.046)\end{array}$ \\
\hline & Relationships with supervisors & & $\begin{array}{l}.207 * * * \\
(.040)\end{array}$ \\
\hline & Stress & & $\begin{array}{l}.057 \\
(.058)\end{array}$ \\
\hline & R2 & .042 & .254 \\
\hline & R2 change & .042 & .212 \\
\hline & F change & $10.938 * * *$ & $21.080^{* * *}$ \\
\hline & Adjusted R2 & .038 & .241 \\
\hline & F statistic & $10.938 * * *$ & $19.414 * * *$ \\
\hline
\end{tabular}

$\mathrm{p}<.05 * / \mathrm{p}<.01 * * / \mathrm{p}<.001 * * *$ 
Table 4: Hierarchical regression analyses for variables predicting PATC (path c)

\begin{tabular}{|c|c|c|c|}
\hline & & Model 1: & Model 2: \\
\hline & & $\begin{array}{l}\text { B } \\
\text { (Std. Error) }\end{array}$ & $\begin{array}{l}\text { B } \\
\text { (Std. Error) }\end{array}$ \\
\hline \multirow[t]{3}{*}{$\begin{array}{l}\text { Step 1: Control } \\
\text { variables }\end{array}$} & Gender & $\begin{array}{l}.027 \\
(.052)\end{array}$ & $\begin{array}{l}.039 \\
(.039)\end{array}$ \\
\hline & Age & $\begin{array}{l}.093 \\
(.034)\end{array}$ & $\begin{array}{l}.065^{*} \\
(.026)\end{array}$ \\
\hline & Org. tenure & $\begin{array}{l}-.015 \\
(.022)\end{array}$ & $\begin{array}{l}-.022 \\
(.017)\end{array}$ \\
\hline \multirow[t]{15}{*}{ Step 2: Independent variables } & Training & & $\begin{array}{l}.011 \\
(.024)\end{array}$ \\
\hline & Prof. dev. & & $\begin{array}{l}.065 \\
(.023)\end{array}$ \\
\hline & Information & & $\begin{array}{l}.207^{* * *} \\
(.029)\end{array}$ \\
\hline & Participation & & $\begin{array}{l}.157^{* * * *} \\
(.030)\end{array}$ \\
\hline & Remuneration & & $\begin{array}{l}.054 \\
(.022)\end{array}$ \\
\hline & Job security & & $\begin{array}{l}.020 \\
(.026)\end{array}$ \\
\hline & Work-life balance & & $\begin{array}{l}.115^{* *} \\
(.022)\end{array}$ \\
\hline & Relationships with colleagues & & $\begin{array}{l}.117^{* * * *} \\
(.029)\end{array}$ \\
\hline & Relationships with supervisors & & $\begin{array}{l}.125^{* *} \\
(.025)\end{array}$ \\
\hline & Stress & & $\begin{array}{l}-.122 * * * \\
(.036)\end{array}$ \\
\hline & R2 & .009 & .458 \\
\hline & R2 change & .009 & .449 \\
\hline & F change & 2.181 & $61.350^{* * *}$ \\
\hline & Adjusted R2 & .005 & .448 \\
\hline & F statistic & 2.181 & $48.099 * * *$ \\
\hline
\end{tabular}

$\mathrm{p}<.05 * / \mathrm{p}<.01 * * / \mathrm{p}<.001 * * *$ 
Table 5: Mediation model: regression statistics for independent variables and PATC while the mediator is fixed

\begin{tabular}{|c|c|c|c|}
\hline & & Model 1: & Model 2: \\
\hline & & $\begin{array}{l}\text { B } \\
\text { (Std. Error) }\end{array}$ & $\begin{array}{l}\text { B } \\
\text { (Std. Error) }\end{array}$ \\
\hline \multirow[t]{4}{*}{ Step 1: Independent variables: } & Information & $\begin{array}{l}.266 * * * \\
(.028)\end{array}$ & $\begin{array}{l}.242 * * * \\
(.029)\end{array}$ \\
\hline & Participation & $\begin{array}{l}.217 * * * \\
(.028)\end{array}$ & $\begin{array}{l}.202 * * * \\
(.028)\end{array}$ \\
\hline & Relationships with colleagues & $\begin{array}{l}.170^{* * * *} \\
(.027)\end{array}$ & $\begin{array}{l}.160 * * * \\
(.027)\end{array}$ \\
\hline & Relationships with supervisors & $\begin{array}{l}.179 * * * \\
(.023)\end{array}$ & $\begin{array}{l}.157^{* * *} \\
(.023)\end{array}$ \\
\hline \multirow[t]{6}{*}{ Step 2: OC } & $\mathrm{OC}$ & & $\begin{array}{l}.121^{* * * *} \\
(.022)\end{array}$ \\
\hline & R2 & .412 & .424 \\
\hline & R2 change & .412 & .011 \\
\hline & F change & $140.901 * * *$ & $15.815^{* * *}$ \\
\hline & Adjusted R2 & 409 & 420 \\
\hline & F statistic & $140.901 * * *$ & $117.964^{* * *}$ \\
\hline
\end{tabular}

$\mathrm{p}<.05 * / \mathrm{p}<.01 * * / \mathrm{p}<.001 * * *$

Table 6: Testing partial mediation effects of OC (Sobel test)

\begin{tabular}{|l|c|c|c|c|c|}
\hline & $\boldsymbol{\beta a}$ & $\boldsymbol{\beta b}$ & $\mathbf{S E a}$ & SEb & $\mathbf{Z}$ \\
\hline Information & $.159^{* * *}$ & $.393^{* * *}$ & .047 & .024 & $3.31^{* * *}$ \\
\hline Participation & $.132^{* *}$ & $.393^{* * *}$ & .048 & .024 & $2.71^{* * *}$ \\
\hline $\begin{array}{l}\text { Relationships with } \\
\text { colleagues }\end{array}$ & $.073^{*}$ & $.393^{* * *}$ & .046 & .024 & 1.57 NS \\
\hline $\begin{array}{l}\text { Relationships with } \\
\text { supervisors }\end{array}$ & $.207^{* * *}$ & $.393^{* * *}$ & .040 & .024 & $4.93^{* * *}$ \\
\hline
\end{tabular}

$\mathrm{p}<.05 * / \mathrm{p}<.01 * * / \mathrm{p}<.001 * * *$ 


\section{Appendix:}

Items used in this research:

\begin{tabular}{|c|c|c|}
\hline \multirow[t]{3}{*}{$\begin{array}{l}\text { Control } \\
\text { variables: }\end{array}$} & Gender: & $\begin{array}{l}\text { Female }=1 \\
\text { Male }=2\end{array}$ \\
\hline & Age: & $\begin{array}{l}\text { Six categories: } \\
20 \text { years old and less }=1 \\
21-30=2 \\
31-40=3 \\
41-50=4 \\
51-60=5 \\
61 \text { and } \text { more }=6\end{array}$ \\
\hline & $\begin{array}{r}\text { Organizational } \\
\text { tenure: }\end{array}$ & $\begin{array}{l}\text { Seven categories: } \\
\text { Less than one year }=1 \\
1-2=2 \\
3-5=3 \\
6-10=4 \\
11-15=5 \\
16-24=6 \\
25 \text { and } \text { more }=7\end{array}$ \\
\hline $\begin{array}{l}\text { Dependent } \\
\text { variables: }\end{array}$ & $\begin{array}{r}\text { Positive } \\
\text { attitudes } \\
\text { towards change }\end{array}$ & $\begin{array}{l}6 \text { items coded } 1-5 \text { (very unfavorable - very favorable) } \\
\text { According to you, have recent organizational changes had a favorable or unfavorable impact on the } \\
\text { following aspects of your job? } \\
\text { 1. Coordination of activities between colleagues } \\
\text { 2. Teamwork } \\
\text { 3. Management of uncertainties } \\
\text { 4. Rigor in objectives } \\
\text { 5. Flexibility and adaptability to change } \\
\text { 6. Decision making power }\end{array}$ \\
\hline \multicolumn{3}{|l|}{$\begin{array}{l}\text { Independent } \\
\text { variables }\end{array}$} \\
\hline & OC: & $\begin{array}{l}\text { Coded } 1-5 \text { (strongly disagree-strongly agree) } \\
\text { 1. I feel that I am emotionally attached to my organization } \\
\text { 2. I feel a strong sense of belonging to this organization } \\
\text { 3. I have everything to gain by staying in my hospital in the longterm }\end{array}$ \\
\hline $\begin{array}{l}\text { Human } \\
\text { resources }\end{array}$ & & $\begin{array}{l}\text { Coded 1-5 (very unsatisfactory-very satisfactory): How would you characterize the following aspects of } \\
\text { your job? }\end{array}$ \\
\hline practices & $\begin{array}{r}\text { Training } \\
\text { opportunies: }\end{array}$ & 1. Continuing education opportunities \\
\hline
\end{tabular}

Professional Coded 1-5 (very unsatisfactory-very satisfactory): How would you characterize the following aspects of developement your job?

1. Opportunities for promotion, career

Information, Coded 1-5 (very unsatisfactory-very satisfactory): How would you characterize the following aspects of communication your job?

1. Communication inside your hospital

2. Information management in the hospital

Employee voice Coded 1-5 (very unsatisfactory-very satisfactory): How would you characterize the following aspects of and your job?

participation 1. Involvement in decision making

2. Degree of autonomy

Compensation Coded 1-5 (very unsatisfactory-very satisfactory): How would you characterize the following aspects of your job?

1. Wage policy 
Article accepted for publication in « Public Personnel Management »

Job security Coded 1-5 (very unsatisfactory-very satisfactory): How would you characterize the following aspects of your job?

1. Employment stability

Relationships Coded 1-5 (very unsatisfactory-very satisfactory): How would you characterize the following aspects of with colleagues your job?

1. Relationships with your colleagues

2. Support of your colleagues in your tasks

Relationships Coded 1-5 (very unsatisfactory-very satisfactory): How would you characterize the following aspects of with your job?

supervisors 1. Relationships with your supervisors

2. Support of your supervisors in your tasks

3. Enhancement of the positive aspects of your business by your supervisors

4. Recognition from your supervisors

Work-life Coded 1-5 (very unsatisfactory-very satisfactory): How would you characterize the following aspects of balance your job?

1. Balance between your work life and your private life

Stress Coded 1-5 (never - very often): During your professional activities in the last month...

perception 1. Have you felt that you could not come to grips with everything you had to do?

2. Have you found yourself thinking about all the work that was left to do?

3. Have you felt overwhelmed by work difficulties? 